\title{
JRC2008-63053
}

\section{POST TEST REVIEW OF A SINGLE CAR TEST OF MULTI-LEVEL PASSENGER EQUIPMENT}

\author{
Michelle Priante \\ US Department of Transportation \\ Volpe Center \\ Cambridge, MA
}

\begin{abstract}
In support of the Federal Railroad Administration's (FRA) Railroad Equipment Safety Program, a full-scale dynamic single car impact test of multi-level passenger equipment was conducted on October 2, 2007. The purpose of the test was to evaluate the crashworthiness performance of a multi-level car. The car struck the test barrier at 36.6 miles per hour (mph). Instrumentation on the car measured the deformations of critical structural elements; the vertical, lateral and longitudinal accelerations of the car body and trucks; and the suspension displacements.

The structure of a multi-level car is different from that of a single level car or bi-level car. The underframe for single level cars and bi-level cars are straight. In a multi-level car, the underframe is at one level for the mezzanines, and at a lower level at the midsection. A transition structure, or gooseneck, connects the levels. Two passenger train incidents in the last few years have shown that multi-level cars deform in different modes from single level cars under dynamic loading conditions. In two separate collisions in Placentia and Glendale, CA, the gooseneck crushed.

During the test, the most damage occurred in the draft sill. The gooseneck was beginning to hinge. The truck connections at both the leading and rear truck failed. Test results show that the multi-level car had a higher average force than the single level car. The secondary impact velocity is higher for the conventional multi-level car than in the conventional single level car. The multi-level car crushed approximately 2 feet during the test, 3 feet less than the single level car crushed.
\end{abstract}

\section{INTRODUCTION}

There has been extensive research on the crashworthiness of single level passenger cars in recent years. The research has involved collision investigations, engineering models, and full- scale tests. The knowledge gained from these studies has led to the development of improved passenger equipment.

Although the research efforts have until recently focused on single level cars, many rail authorities in the United States run alternative equipment with bi-level or multi-level structures. The differences in underframe design between the single level and multi-level cars, in conjunction with accident observations of alternative failure modes, have demonstrated the need for further study of this class of equipment.

The single car test of multi-level equipment described in this paper was designed to help evaluate the crashworthiness of a multi-level car in a controlled collision. The data collected from this test will be used to refine engineering models. The knowledge gained from this test will be used to evaluate the behavior of a consist of multi-level equipment in a manner similar to the work performed on single level equipment [1].

\section{PASSENGER CRASHWORTHINESS PROGRAM}

An ongoing effort has been to evaluate current passenger equipment with the intention of using the knowledge gained from the evaluation to design improved equipment. This improved equipment is designed to save passenger lives and reduce injuries in the event of a collision. The concepts of a crush zone and improved interior configurations are being introduced into passenger rail equipment. Table 1 lists the full scale tests that have been performed or are being planned as part of this effort. 
Table 1. Passenger Equipment Full-Scale Tests

\begin{tabular}{|c|c|c|c|}
\hline $\begin{array}{c}\text { Test } \\
\text { Conditions }\end{array}$ & Levels & $\begin{array}{c}\text { Conventional } \\
\text { Equipment }\end{array}$ & $\begin{array}{c}\text { Improved } \\
\text { Equipment }\end{array}$ \\
\hline $\begin{array}{c}\text { Single Car into } \\
\text { Wall }\end{array}$ & Single & $\begin{array}{c}\text { November 16, } \\
1999\end{array}$ & $\begin{array}{c}\text { December 3, } \\
2003\end{array}$ \\
\hline $\begin{array}{c}\text { Two Cars into } \\
\text { Wall }\end{array}$ & Single & April 4, 2000 & $\begin{array}{c}\text { February 26, } \\
2004\end{array}$ \\
\hline Train to Train & Single & $\begin{array}{c}\text { January 31, } \\
2002\end{array}$ & $\begin{array}{c}\text { March 23, } \\
2006\end{array}$ \\
\hline $\begin{array}{c}\text { Single Car } \\
\text { into Wall }\end{array}$ & Multiple & $\begin{array}{c}\text { October 2, } \\
\mathbf{2 0 0 7}\end{array}$ \\
\hline
\end{tabular}

The completed conventional tests were intended to establish performance of the existing single-level fleet. In the single-car test, the critical measurements yielded a force-crush characteristic and the gross motions of the test equipment. The two-car test added consideration of the interactions of the coupled connection, i.e. measuring the vertical and lateral motions of the cars with respect to each other and observing the potential for sawtooth lateral buckling to occur. The train-totrain test focuses on the interactions of the colliding equipment, i.e. how the equipment engages and the potential for override of the colliding vehicles. Table 2 lists the key measurements made during each test.

Table 2. Test Descriptions and Critical Measurements

\begin{tabular}{|l|l|}
\hline Test Description & Key Observations \\
\hline Single-Car test & $\begin{array}{l}\text { - Modes of deformation } \\
\text { - Dynamic crush force } \\
\text { - Gross motions of vehicles }\end{array}$ \\
\hline Two-Car Test & - Interactions of coupled cars \\
\hline Train-to-Train Test & $\begin{array}{l}\text { - Interactions of colliding equipment } \\
\text { - Override of colliding cars } \\
\text { - Lateral buckling of coupled cars }\end{array}$ \\
\hline
\end{tabular}

The next planned test of multi-level equipment is a two car test similar to the single level tests. An analysis of a train-totrain scenario with multi-level cars will use information from the one and two car tests.

Underframe Comparison A major structural difference between single level cars and multi-level cars is the underframe. For a single level car, the underframe is straight. In a multi-level car, the underframe is not straight. The underframe is at one height for the mezzanines on either end of the car and has a lower height for the bi-level midsection. A gooseneck connects the two levels. This gooseneck region has the potential for preferential crush. Figure 1 compares the single level underframe with the multi-level underframe. The goosenecks are circled.

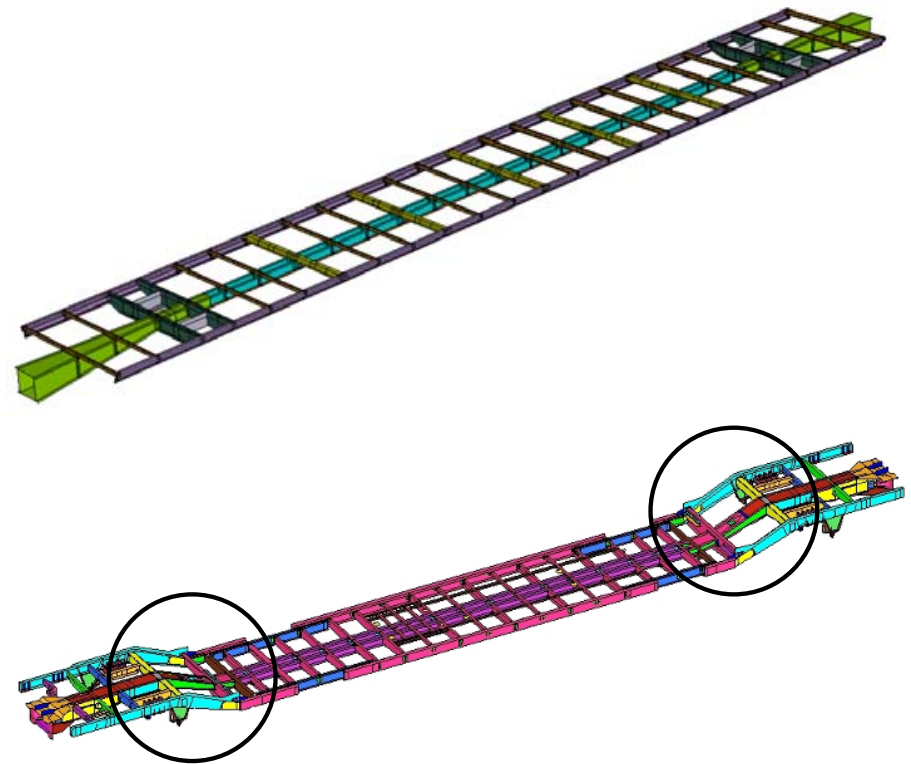

Figure 1. Single Level Car Underframe (Top) Multi-Level Car Underframe (Bottom)

\section{MULTI-LEVEL STRUCTURE INVESTIGATIONS}

Part of the research on passenger cars involves investigating rail collisions where there has been fatalities, a large number of injuries, or significant structural damage. Two of these field investigations have involved multi-level cars.

Collision in Placentia, California On April 23 ${ }^{\text {rd }}$, 2002, an eastbound freight train approached a westbound passenger train on the same track in Placentia, California. The conductor of the passenger train brought the train to a complete stop. The freight train, which was on full emergency braking at the time, collided with the passenger train. The passenger train had been traveling in a cab car leading arrangement, where the cab car was the westernmost car in the passenger train $[2,3]$. Thus, the lead locomotive in the freight train collided with the cab car of the passenger train.

In a typical head-on collision, the impacted end of the car is expected to crush longitudinally, parallel to the tracks. However, in this case, the majority of the crush occurred towards the rear of the lead car in the passenger train and perpendicular to the tracks, as shown in Figure 2. Figure 3 shows the impacted end of the cab car, which had very little damage. The structural deformation occurred at the rear gooseneck. The lateral accelerations generated by this form of structural collapse aggravated the loss of compartmentalization of the occupants. These accelerations, combined with already severe longitudinal accelerations, made for a notably harsh occupant environment [4]. 


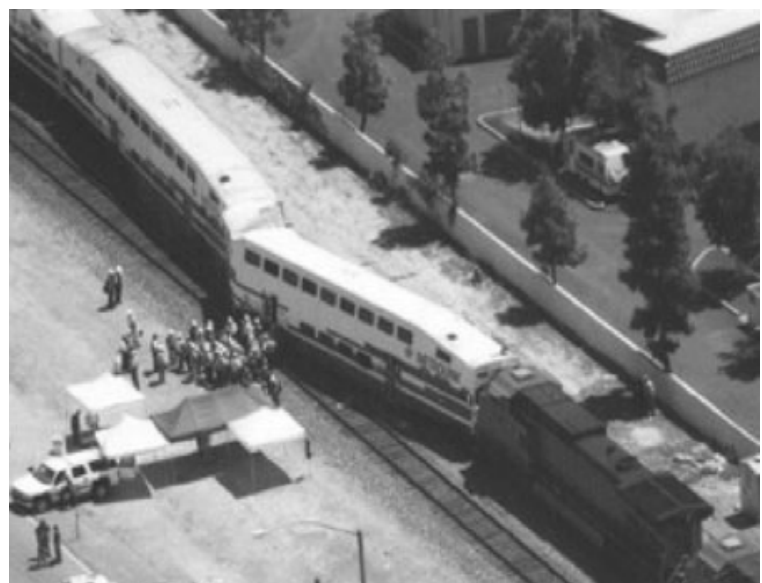

Figure 2. Damage to MetroLink Cab Car after Collision with Locomotive-Led Freight Train



Figure 3. The Leading End of the Cab Car has Little Damage

Collision in Glendale, California On January 26, 2005, a series of collisions involving three trains and an sports utility vehicle (SUV) occurred in Glendale, California. The collision caused 11 fatalities.

Eight of the 11 fatalities occurred in Train 100, the southbound cab car led passenger train. The first collision occurred between Train 100 and an SUV. A solid piece from the SUV interacted with the switch components in such a way that the leading end of the cab car entered a siding. The back end of the cab car and the trailing equipment remained on the mainline track. The second collision was between Train 100 and a freight train parked in the siding. The leading end of the cab car impacted a six-axle freight locomotive coupled to a second sixaxle freight locomotive that was coupled to a number of cars loaded with ballast. The impact with the freight locomotive crushed the leading end of the cab car, shortening the cab car by more than 26 feet. In the third collision, the back end of Train 100's cab car swung around and impacted the side of Train 901, which was traveling north.
Figure 4 shows the underframe of the cab car of train 100. The cab car crushed up to the first gooseneck. Figure 5 shows the side sill and gooseneck of the mezzanine, which was separated from the leading end of the cab car during the collision. The leading end of the side sill is at the bottom left of this picture. At the top right of the picture is the gooseneck. As shown in the picture, the gooseneck bent to a right angle during the collision at one end and separated from the car entirely at the other end.

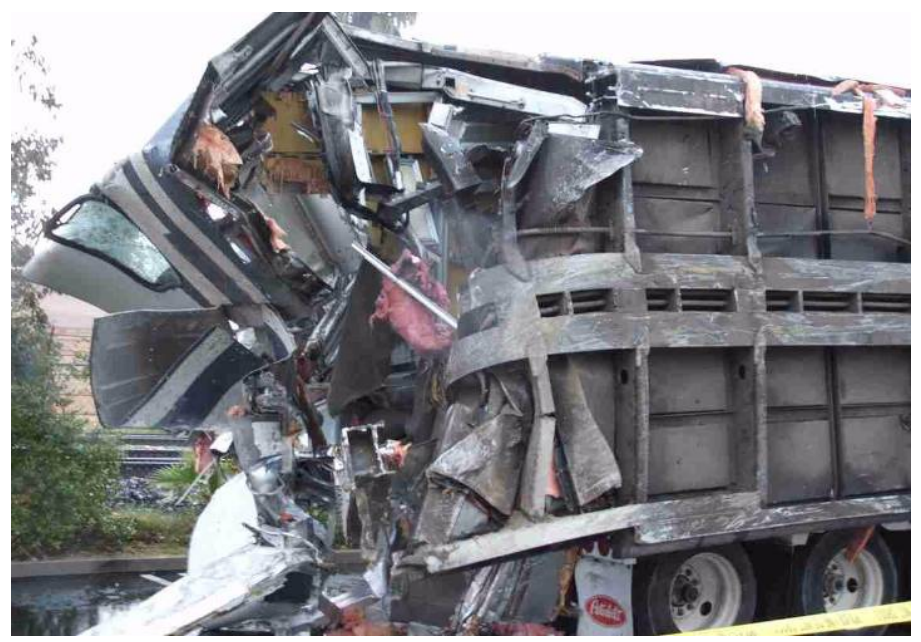

Figure 4. The Underframe of Cab Car Crushed up to the Gooseneck

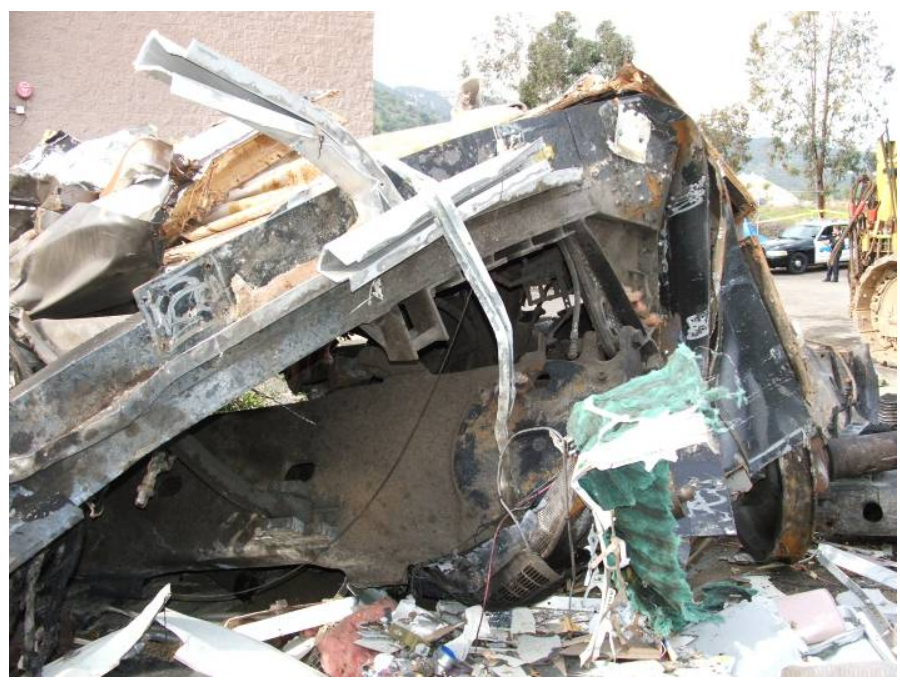

Figure 5. The Side Sill and the Crushed Gooseneck

\section{PRE-TEST ANALYSES}

Both pre-test finite element models and pretest lumped parameter collision dynamics models produced a preliminary understanding of the behavior of a multi-level car. The finite element models predicted that crush could occur at either the leading end or the gooseneck [5]. A heuristic model, based on the collision in Placentia California, shows that the mode of 
deformation is dependent on the collision velocity [4]. Collision dynamics models demonstrate the importance of the trailing cars in determining the mode of deformation [6].

\section{Potential Failure Modes}

Neither past tests, collision observations, or engineering analyses has been able to give a complete understanding of the crashworthiness of a multi-level car. Prior to the test, a series of predictions for failure modes were given.

In the single car test of single level conventional equipment, the leading end of the car crushed 5 feet [7]. Those results suggest that in a single car test, the leading end will crush. This test prediction is shown first in Figure 6.

Both single car and full train engineering models have been used to evaluate the crash performance of multi-level cars. The finite element models suggest crush at two locations, both the leading end and the gooseneck [5]. Collision dynamics modeling suggests that the leading end or a combination of the leading end and the gooseneck will crush during the test $[6,8]$. From these results, a second prediction for the test is that crush would occur in two places. This is the second prediction in Figure 6.

The collisions in Placentia and Glendale, California involving multi-level cars suggest that the gooseneck will crush while the leading end remains intact. Figure 6 shows this prediction last.
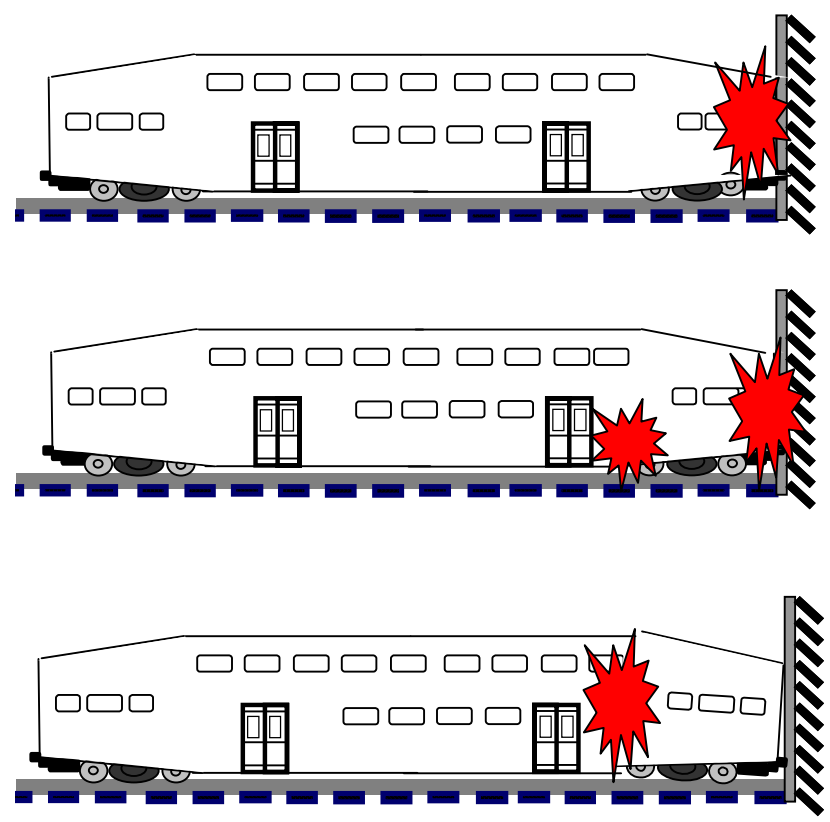

Figure 6. Three Potential Failure Modes for Single Car Test

\section{TEST DESCRIPTION}

The objective of the test was to evaluate the crashworthiness of a multi-level car in a controlled collision scenario. The controlled test environment allows for observation of the deformation and failure modes of major structural components. Processed test data yields the gross car motions and force-crush characteristics. The processed data improves the engineering models.

The single car test of multi-level equipment occurred at the Transportation Technology Center in Pueblo, Colorado on October 2, 2007. The weight of the car at test time was 95,400 $\mathrm{lb}$. The test speed was $36.6 \mathrm{mph}$.

Several types of data collecting instruments documented the test. There were 17 accelerometers, 19 displacement transducers, 36 strain gages and 11 video cameras. Instrumentation on the car captured gross motions, force-crush behavior and local deformations. The Appendix contains detailed information about the instrumentation.

\section{TEST RESULTS}

Figure 7 shows the impact end of the car after the test. Damage to the exterior of the car is on the paneling at the leading end, along the roofline and at the transition structure. There is damage at the truck connections, the center sill outboard of the bolster, and at the side sills. There are signs of failure initiation at the gooseneck.

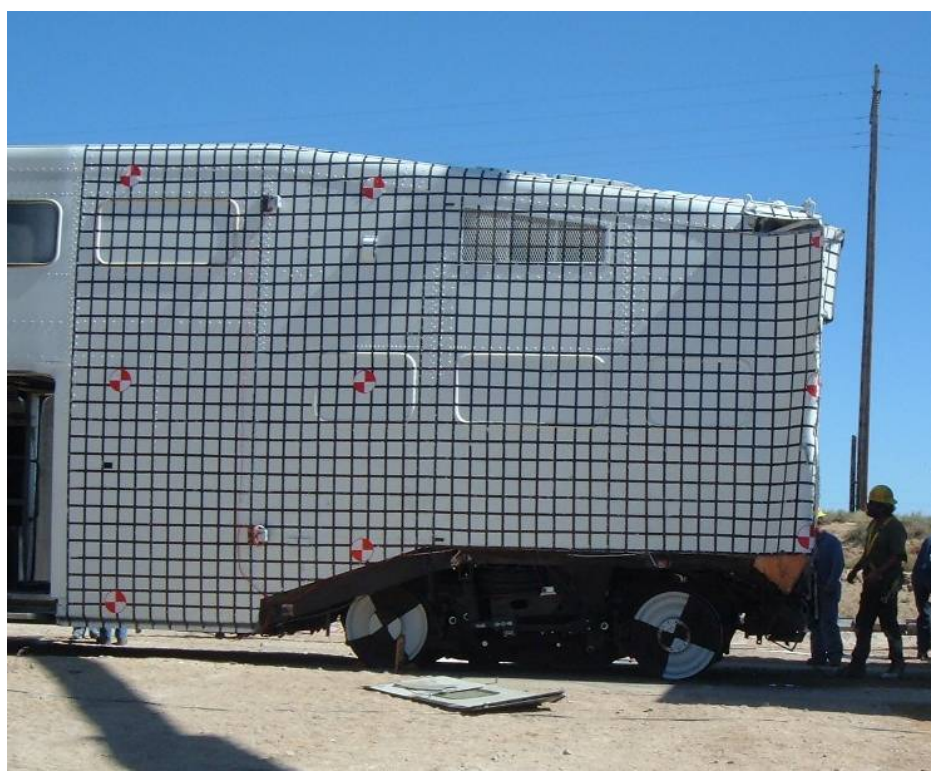

Figure 7. Post-test Side View of the Impact End of the Car

The underframe of the car crushed primarily at the center sill, just outboard of the bolster at the impact end. The circle in Figure 8 surrounds a change in height of the center sill. During the test, the bellmouth hit the wall and pushed the center sill back into the car. The first lateral member on the left side of the car separated from the center sill, as shown in Figure 9. The second lateral member stayed attached to the draft sill, but pushed backwards, as shown on the right side of Figure 10. The center sill stayed intact until the transition from the wide center sill section of the draft sill to the thinner section of the draft sill at the bolster. 


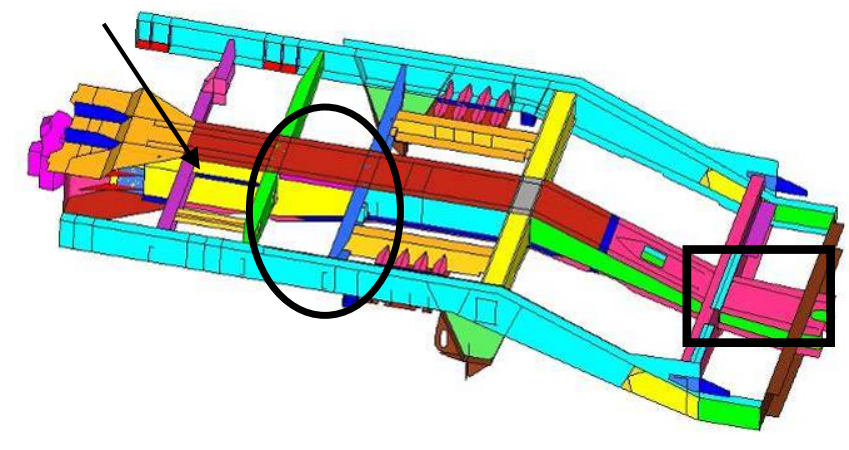

Figure 8. Location of the Draft Sill Failure

The arrow in Figure 8 points to the location of a connection failure. When the draft sill pushed back, the lateral member on the left side completely separated from the draft sill. Figure 9 shows this separation.

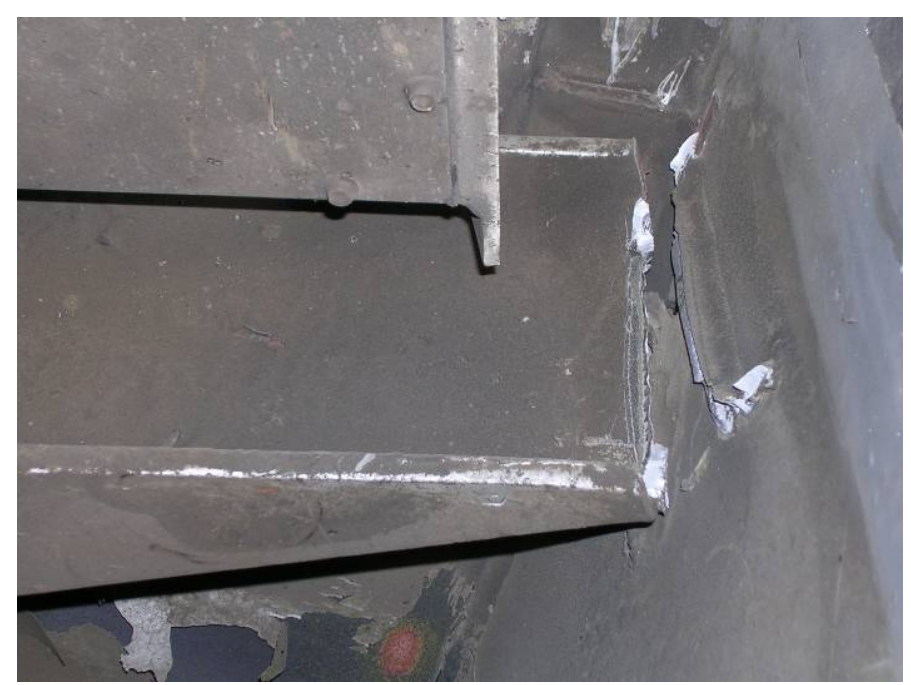

Figure 9. A Lateral Member Separates from the Draft Sill

Figure 10 shows the failure of the center sill. In this failure the collision with the wall pushed the bellmouth back into the car. The circle in Figure 8 highlights the location of this failure. In the center sill, the sides separated from the top and bottom at the weld connections. The lateral member on the left pushed backwards. The lateral member on the right side of the picture is part of the bolster support. Figure 11 shows a bottom and right side sketch of the draft sill failure.

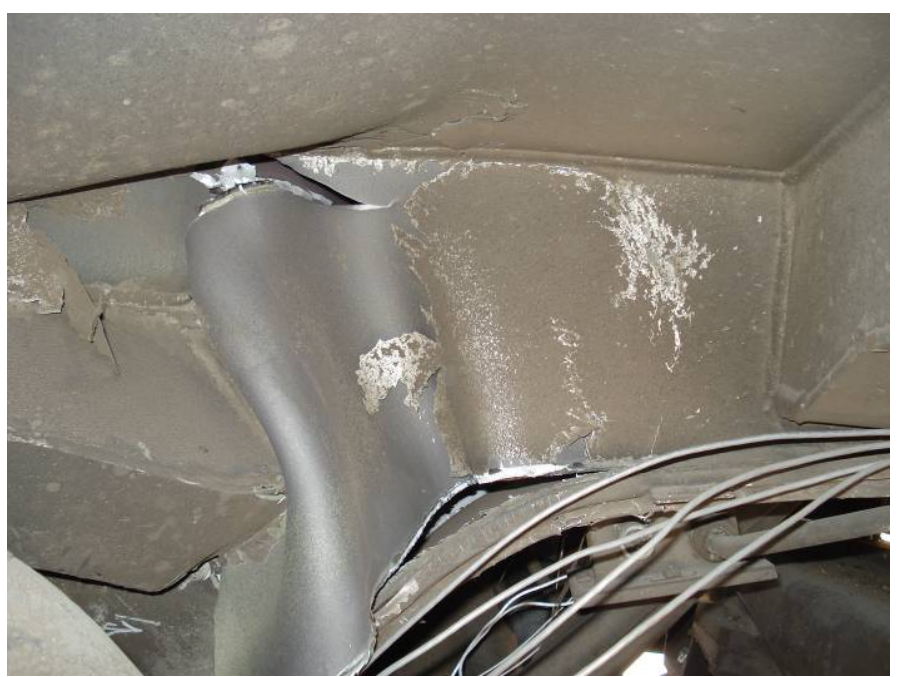

Figure 10. Right Side View of Draft Sill Failure

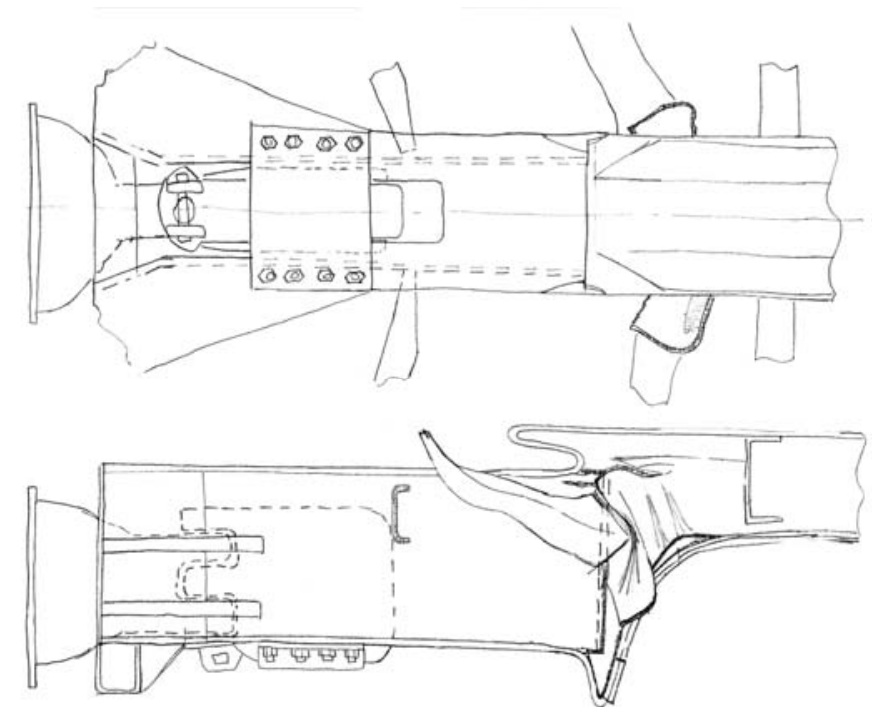

Figure 11. Bottom and Right Side Sketches of the Draft Sill Failure

Although the gooseneck did not suffer total failure or major deformations, inspection after the test revealed evidence of the onset of failure at the location marked with a square in Figure 8. The partially-buckled area is shown in Figure 12. 


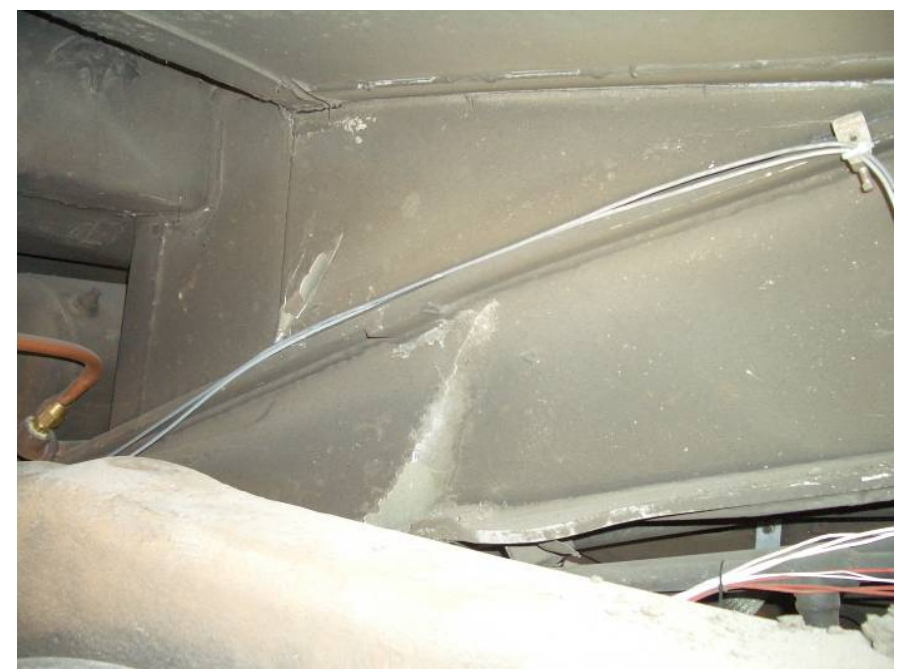

Figure 12. Onset of Gooseneck Hinge

The collision with the wall damaged the fiberglass car exterior at the leading end of the car. Figure 13 shows the damage to the leading end. As is typical to allow for clearance in curves, the ends of the car are curved in plan. The end beam is crowned for curving. During the test, the wall flattened the leading end bow. The fiberglass cracked at the connections between the leading face and the side panels and the roof. The fiberglass also distorted on the right side of the car (as seen in Figure 13). Some of the rivets, particularly along the roofline and at the location of the gooseneck, popped out during or immediately after the test.

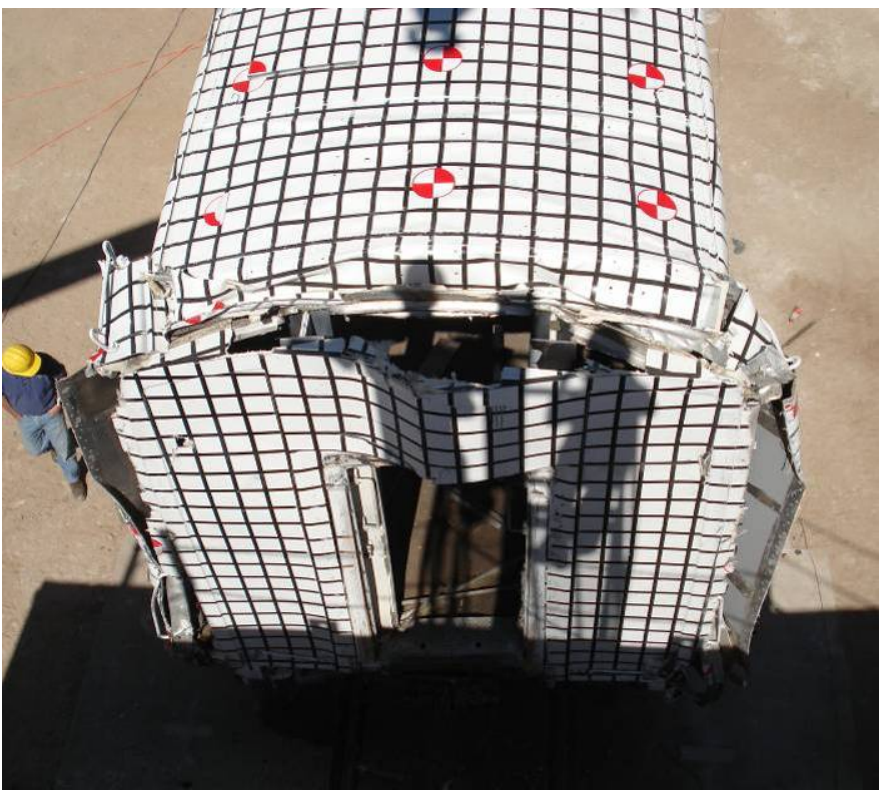

Figure 13. Damage to the Leading End of the Car

During the test, the side sills deformed differently than the center sill. The side sills pushed out away from the car at the leading end. Figure 14 shows a top view sketch of the underframe. The side sills splay out laterally. It appears that the connection of the side sill to the first lateral member helped to stop propagation of the lateral deformation.

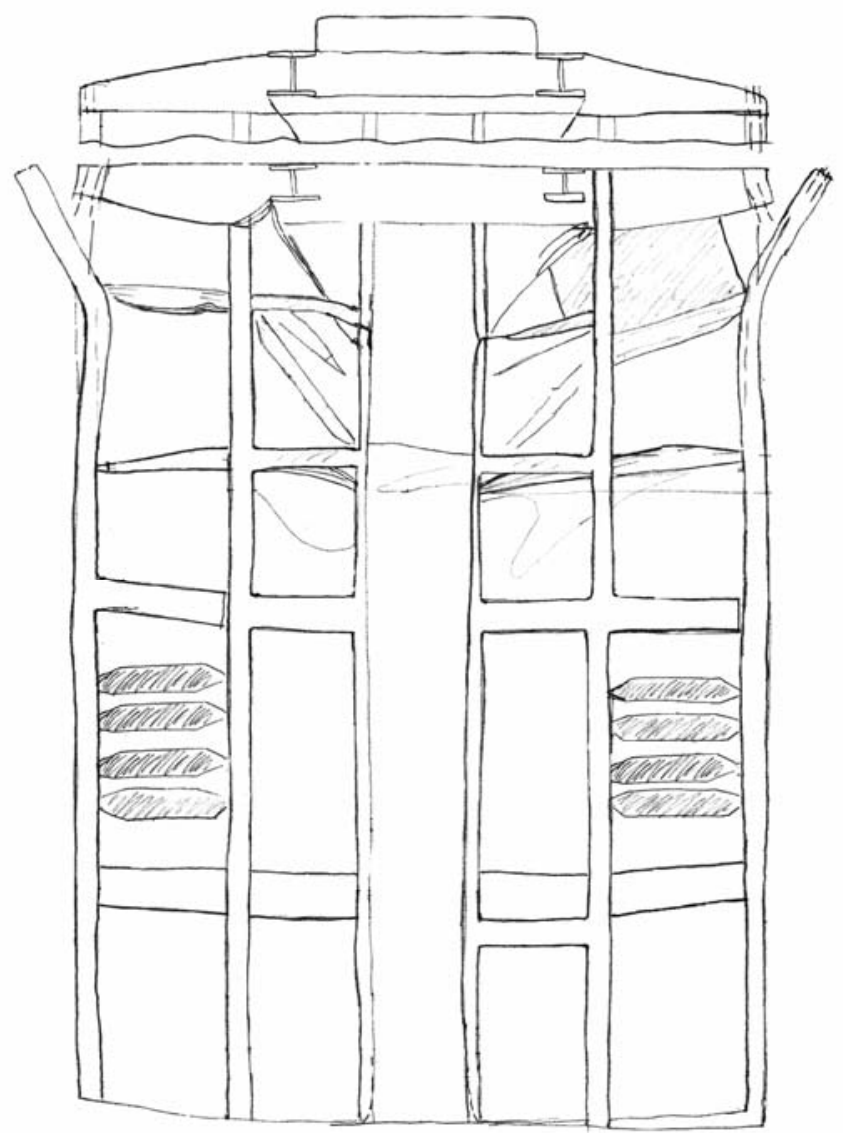

Figure 14. Sketch of the Side Sill Deformation

Figure 15 is a close up photograph taken of the left side sill. The leading end of the side sill moved laterally. Figure 16 shows a close up of the right side sill. The arrow points at the start of the side sill buckle. The buckle appears to start at the attachment to the lateral member, which can also be seen in the photo. 


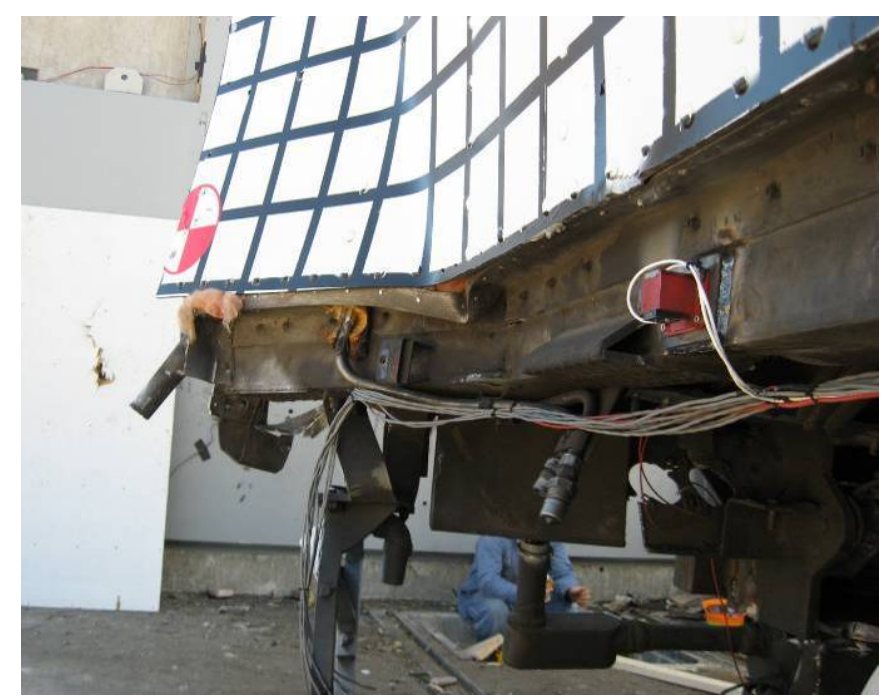

Figure 15. Side Sill Deformation at the Leading End

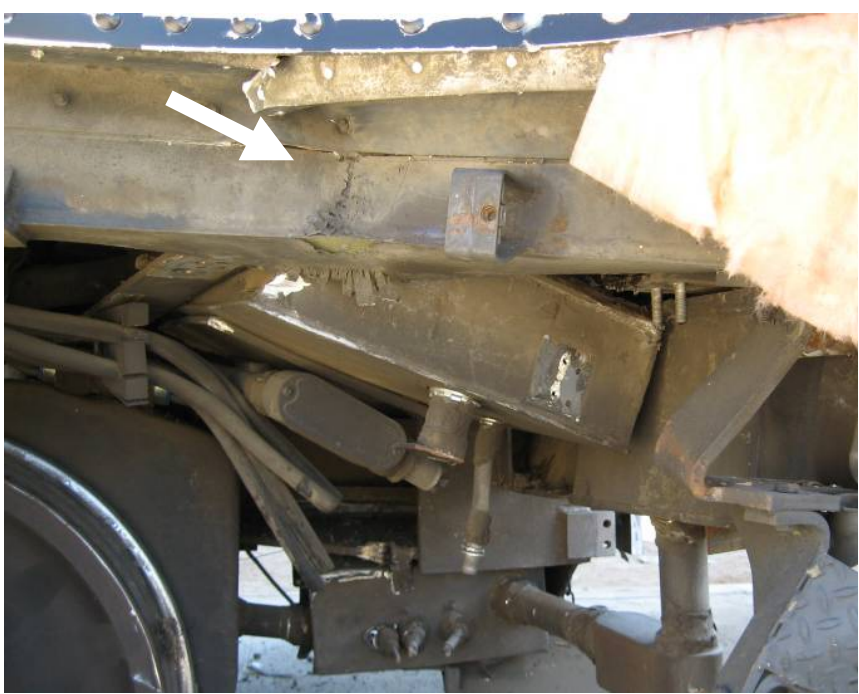

Figure 16. Lateral Buckle of the Right Side Sill

The truck attachments failed during the test. When the car stopped, the truck attachments broke and the trucks continued moving forward for approximately another six inches. Figure 17 shows the sheared primary suspension after the collision. Figure 17 shows the leading truck on the right side. The photograph looks backward from the impact end at the truck attachments.

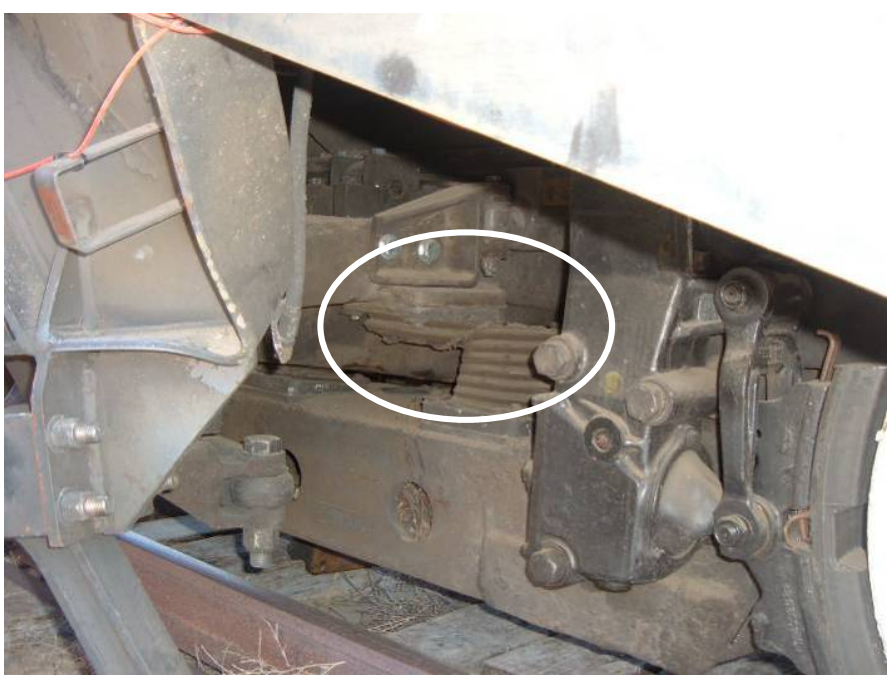

Figure 17. The Leading Right Truck Attachments

Test Data

Processed data from the accelerometers helps to make comparisons between the single level and the multi-level equipment. Figure 18 compares the force displacement behavior of the single car test of single level equipment to the single car test of multi-level equipment [9]. In both cases, longitudinal accelerometers attached to the car body have been filtered using a CFC60 filter. The force calculation for the multi-level car included the accelerometers at the trucks, since the trucks acted as separate masses when they separated from the car during the test. The following equation was used to calculate the force-crush curve for the multi-level car:

$$
F=m_{C B} \cdot a_{C B}+m_{L T} \cdot a_{L T}+m_{B T} \cdot a_{B T}
$$

In this equation subscripts $\mathrm{CB}$, LT and BT stand for car body, leading truck and back truck respectively. The weight of each truck was assumed to be $12,000 \mathrm{lb}$. The carbody weight is calculated as the weight of the trucks subtracted from the total measured weight of the car, 95,400. The displacement on the independent axis is from the car body accelerometers.

Figure 18 shows that the multi-level car and the single level car have a similar initial peak force of approximately $3 \times 10^{6} \mathrm{lbf}$ at a displacement of 3 inches. After the initial peak in force, the single level car crushes at a relatively low force of $5 \times 10^{6} \mathrm{lbf}$. The multi-level car peaks in force a second time and then crushes at a high force of $2 \times 10^{6} \mathrm{lbf}$. For this collision scenario, a multi-level car is much stronger than a single level car. In a different collision scenario, the cars may behave another way. 


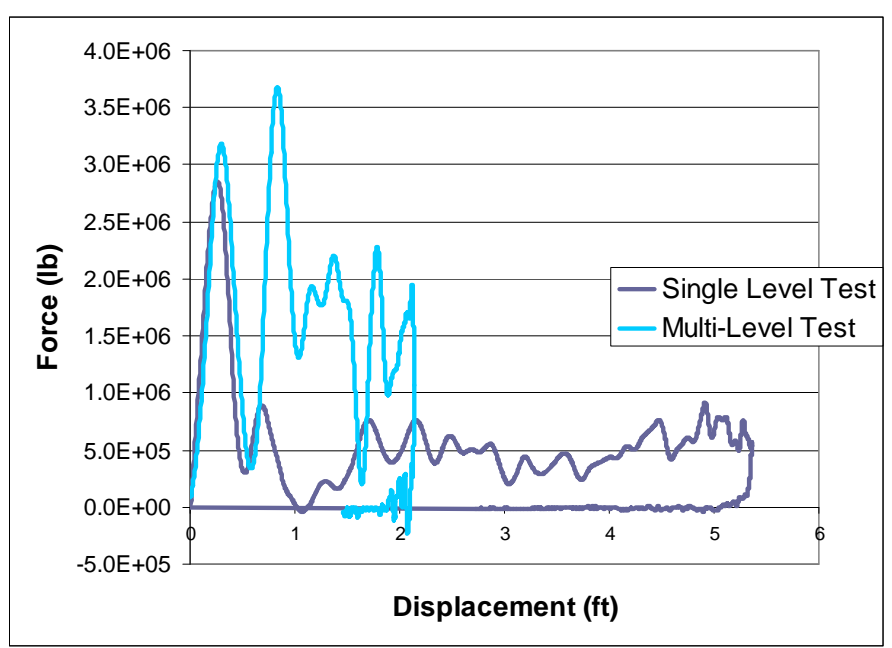

Figure 18. Force vs. Displacement for a Single Level and a Multi-Level Car

Another area of study from the test data is the interior environment, an important indicator of passenger survivability. The secondary impact velocity is a measure of the speed at which a person would hit the interior of the car after traveling the distance to the object in front of them. In Figure 19, data is taken from the single car test of multi-level equipment, the single car test of single level equipment, and an $8 \mathrm{G}$ triangular pulse. The 8G triangular pulse is standard for evaluating interior configurations. Figure 19 shows that for any distance, the multi-level car has a much higher secondary impact velocity, and, therefore, a more severe interior environment than the single level car or the $8 \mathrm{G}$ triangular pulse. This is due to the high force levels over a short crush distance for the multi-level car.

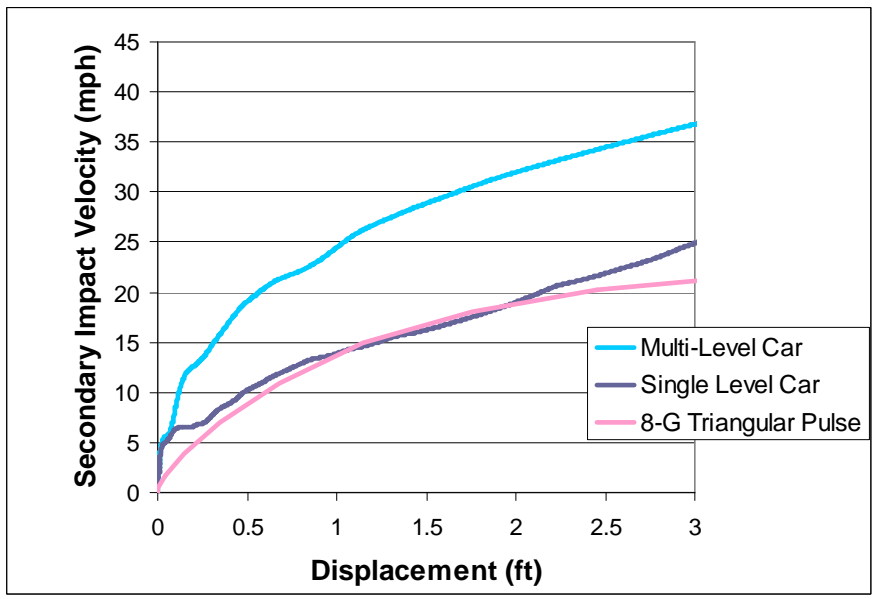

Figure 19. Secondary Impact Velocity Comparison

\section{SUMMARY}

During the test, there was damage to the leading end of the car, the side sills, and draft sill of the bolster. There were also signs of plastic hinge at the gooseneck. The impact damaged the truck connections, allowing the trucks to push forward into the car. The test data shows that there is a higher average force in a multi-level car than in a single level car. The test data also shows that there is a higher secondary impact velocity in the multi-level car than in the single level car.

\section{PLANNED WORK}

An FRA report will include a thorough review of the data collected during the test. Researchers are also comparing test data with model predictions and refining a finite element model based on results from the test. A follow-on paper will present the refined model results.

Since there is evidence in field studies and collision dynamics modeling that the loading conditions greatly influence the mode of crush, a two-car test of multi-level equipment is being tentatively planned for September 2008. To prepare for the test and decide whether to hold the test, the refined finite element model will be used to simulate the twocar test.

Data taken from the single car, and possibly the two-car tests will be extrapolated to a train-to-train scenario. The trainto-train scenario will be analyzed in both finite element and collision dynamic models. The results for these analyses are planned for March 2009.

\section{ACKNOWLEDGMENTS}

The research described in this paper was performed as part of the Equipment Safety Research Program sponsored by the Office of Research and Development of FRA. The author would like to thank Claire Orth, Chief, Equipment and Operating Practices Division, for her support. Eloy Martinez, Program Manager, led this effort. Gunars Spons, FRA Resident Manager at the Transportation Technology Center, managed the full-scale test effort.

The author would like to thank Volpe Center staff David Tyrell, Senior Engineer; Benjamin Perlman, Senior Engineer; Kristine Severson, Senior Engineer, who assisted with supervising the contract with Applied Research Associates and designing the test. The author would also like to thank Volpe Center staff Matt Lyons and Philip Mallon, who performed a post-test autopsy.

The author would like to thank Rob MacNeill of Applied Research Associates for running a pretest finite element model and performing a post test examination of the car, under contract to the Volpe Center. Mr. MacNeill drew the sketches in Figure 11and Figure 14.

The author would like to thank Matthew Witte, Senior Engineer, Transportation Technology Center Inc. (TTCI), who led the TTCI team that implemented the test. The author would like to thank Tom Roderick, Senior Technician, TTCI, for 
inspecting the cars and choosing the appropriate end for the test.

The author would also like to thank METROLINK, the Los Angeles commuter railroad, for donating the multi-level car used in this test. The author would like to specifically thank Bill Lydon, Art Mallette and Ron Svoboda of METROLINK for their roles in this effort.

\section{REFERENCES}

1. Tyrell, D., "Passenger Rail Train-to-Train Impact Test Volume I: Overview and Selected Results," US Department of Transportation, DOT/FRA/ORD-03/17.I, July 2003.

2. National Transportation Safety Board, "Head-On Collision Between BNSF and Metrolink Trains, and Subsequent Derailment, in Placentia, California on April 23, 2002: Factual Report, Survival Factors Issues.” DCA-02-MR-004, 2/20/03.

3. National Transportation Safety Board. 2003. Collision of Burlington Northern Santa Fe Freight Train with Metrolink Passenger Train Placentia, California, April 23, 2002. Railroad Accident Report NTSB/RAR-03/04. Washington, DC.

4. Parent, D., Tyrell, D., Perlman, A.B., "Crashworthiness Analysis of the Placentia, CA Rail Collision,” Proceedings of ICrash 2004, International Crashworthiness Conference, San Francisco, California, July 14-16, 2004.

5. Martinez , E., Zolock, J., Tyrell, D., "Crush Analysis of Multi-Level Equipment," American Society of Mechanical Engineers, Paper No. IMECE2006-13214, November 2006.

6. Priante, M., "A Collision Dynamics Model of a Bi-Level Car,” Tufts University Master's Thesis, May 2006.

7. Tyrell, D., Severson, K., Perlman, A.B., "Single Passenger Rail Car Impact Test Volume I: Overview and Selected Results," US Department of Transportation, DOT/FRA/ORD00/02.1, March 2000.

8. Priante, M., Tyrell, D., Perlman, A.B., "A Collision Dynamics Model of a Multi-Level Train,” American Society of Mechanical Engineers, Paper No. IMECE2006-13537, November 2006.

9. Severson, K., "Development of Collision Dynamics Models to Estimate the Results of Full-scale Rail Vehicle Impact Tests," Tufts University Master's Thesis, November 2000.

\section{APPENDIX: INSTRUMENTATION}

The objectives of the instrumentation for the test were to measure the performance of structural elements, capture the timing of events, measure the load paths into the occupied volume, and develop composite force-crush characteristics. Accelerometers measured the car body rigid motion trajectory, strain gages and string potentiometers measured local deformations and load paths.

In total, there were 45 accelerometers, 36 strain gages and 10 displacement transducers recording data. The data was sampled at 10,000 Hz. Data was recorded from 1 second before the car hit the wall until 4 seconds after the car hit the wall. The first 0.1 seconds of data after the car hit the wall contained most of the collision information.

Figure A1 shows the locations of the accelerometers on the center sill and side sills. The accelerometers on the center sill measured acceleration in three directions and the accelerometers on the side sills measured longitudinal and lateral accelerations. There were two three-dimensional accelerometers on the leading coupler and lateral and longitudinal accelerometers on each truck.

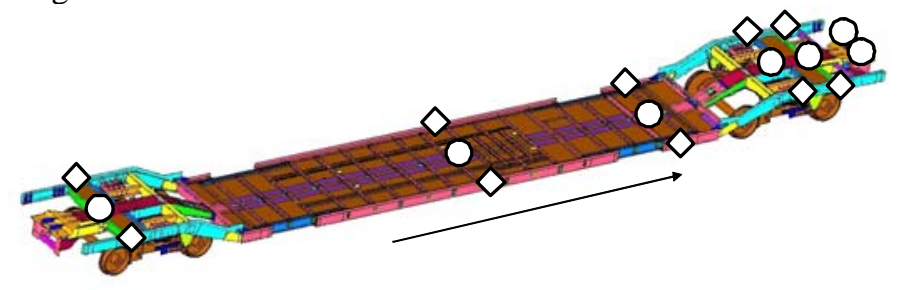

Figure A1. Accelerometer locations

The strain gages in the test are intended to check the event timing. They are standard longitudinal strain gages. Figure A2 shows strain gage locations for the cant rail and side sills. The strain gages were located on the left and right side of the car. Two strain gages were in each location. Figure A3 shows the strain gage locations on the center sill. Four strain gages were in each location.

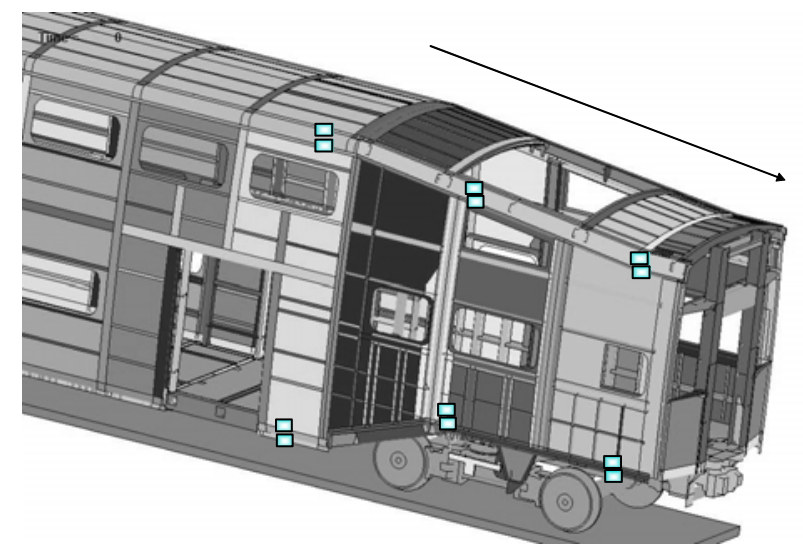

Figure A2. Strain gage location on the cant rails and side sills 


\section{미 End View}

독ain Gages

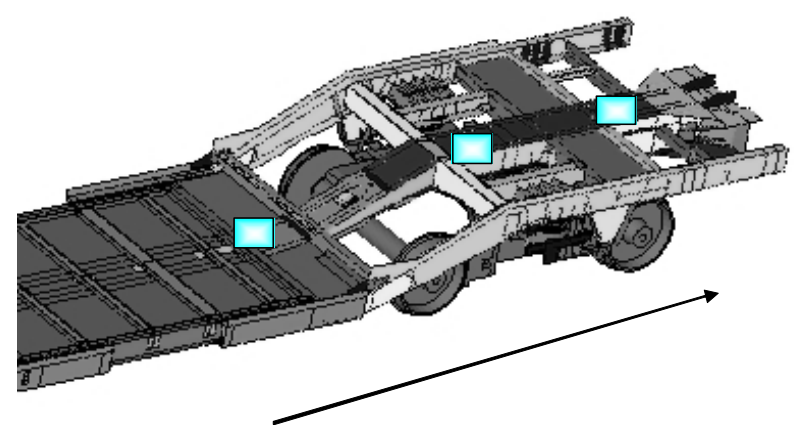

Figure A3. Strain gage location on the Center Sill

Figure A4 shows the displacement transducer locations for the right side of the car. The configuration was the same on the left side of the car. There were two longitudinal displacement transducers on the impact coupler. Each spring group on the leading and rear trucks had a vertical displacement transducer.

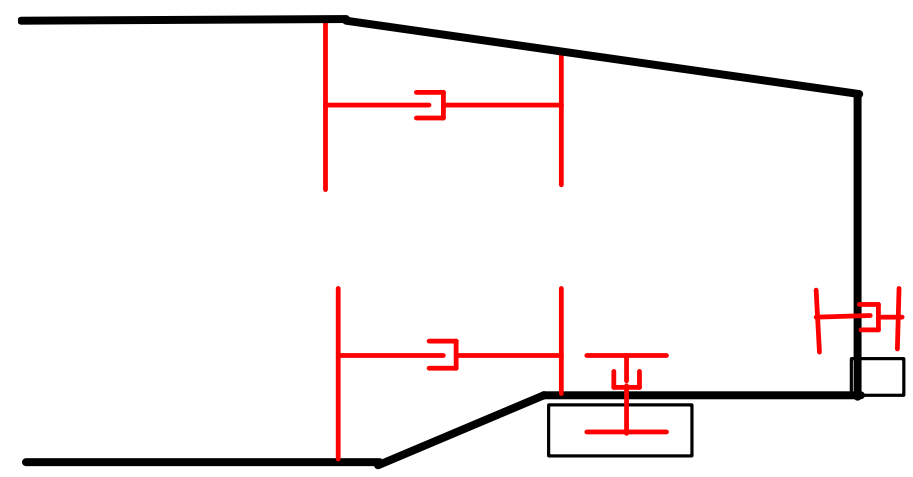

Figure A4. Displacement transducer locations 